\title{
PENGEMBANGAN MEDIA PEMBELAJARAN MATEMATIKA HAND QUICK PADA MATERI OPERASI BILANGAN BULAT SISWA KELAS VII
}

\author{
Ririn Dwi Agustin ${ }^{1}$, Rochsun ${ }^{2}$ \\ ${ }^{1,2}$ Program Studi Pendidikan Matematika, IKIP Budi Utomo Malang \\ Email: 1 ririndwiagustin@budiutomomalang.ac.id \\ rochsun@budiutomomalang.ac.id
}

\begin{abstract}
Abstrak
Penelitian ini bertujuan untuk menghasilkan media pembelajaran matematika yang Hand Quick untuk siswa kelas VII MTs. Mafatihul Huda Pujon pada materi Bilangan Bulat. Penelitian ini di kembangkan dengan model ADDIE, yang meliputi tahap Analysis, Design, Development, Implementation dan Evaluation. Penelitian ini menghasilkan media pembelajaran matematika Hand Quick pada operasi bilangan bulat. Hasil penelitian menunjukkan bahwa:(1) Dari hasil analisis angket respon siswa diperoleh skor sebesar 3,8 dan di kategorikan efektif. (2) dari hasil analisis kevalidan diperoleh skor 3,16 yang termasuk dalam kategori valid. Berdasarkan hasil analisis kevalidan dan keefektifan maka bisa disimpulkan bahwa media Hand Quick termasuk dalam kategori baik dan layak digunakan.
\end{abstract}

Kata Kunci: Media, Hand Quick, Bilangan Bulat

\begin{abstract}
This study aims to produce a Hand Quick mathematics learning media for grade VII students of MTs. Miftahul Huda Pujon on Round Number material. This research was developed with the ADDIE model, which includes the Analysis, Design, Development, Implementation and Evaluation stages. This research produces Hand Quick mathematics learning media on integer operations. The results showed that: (1) From the results of the analysis of the questionnaire responses of students obtained a score of 3.8 and categorized as effective. (2) the validity analysis results obtained a score of 3.16 which is included in the valid category. Based on the results of the validity and effectiveness analysis, it can be concluded that the Hand Quick media is included in the good and proper category.
\end{abstract}

Keywords: Media, Hand Quick, Integer

\section{PENDAHULUAN}

Perkembangan teknologi informasi saat ini sudah mulai merambah ke berbagai bidang kehidupan dan tidak dapat dipungkiri bahwa teknologi informasi dapat meningkatkan efektivitas dan efisiensi kerja suatu organisasi. Oleh karena itu, sebelum mengimplementasikannya, sebaiknya pengembang sistem memiliki pemahaman mengenai faktor-faktor yang dapat mempengaruhi perilaku pemakai dalam memanfaatkan TI (Darmini, 2009). Kondisi seperti ini merupakan kesempatan besar untuk meningkatkan mutu pendidikan bangsa. Namun pada sisi lain, hal ini merupakan tantangan bagi para guru. Sebagai refleksinya, guru harus menemukan metode pembelajaran yang relevan, karena metode lama saat ini dinilai kurang efektif dalam kegiatan pembelajaran. Selain itu, siswa lebih tertarik dengan pembelajaran yang langsung mengajak mereka untuk aktif, dari pada hanya sekedar mencatat dan mendengarkan guru menerangkan.

Dalam Peraturan Pemerintah nomor 19 tahun 2005 pasal 19 Ayat 2 disebutkan bahwa proses pembelajaran pada satuan pendidikan diselenggarakan secara interaktif, inspiratif, menyenangkan, menantang, memotivasi peserta didik untuk berpartisipasi aktif,serta memberikan ruang yang cukup 
bagi prakasa, kreativitas, dan kemandirian sesuai dengan bakat, minat, dan perkembangan fisik serta psikologis peserta didik.

Oleh sebab itu, guru diharapkanmampu memaksimalkan perannya sebagai aktor utama dalam pendidikan, yakni menciptakan suasana pembelajaran yang interaktif dan menyenangkan. Tentunya dengan metode pembelajaran yang telah diperbaharui dan dilengkapi media pembelajaran yang mampu menumbuhkan daya tarik tersendiri bagi siswa, sehingga pembelajaran tidak terus-menerus berpusat pada LKS (Lembar Kerja Siswa) ataupun buku paket seperti pada umumnya.

Miarso (2004) media pada umumnya adalah sebuah alat yang mempunyai fungsi untuk menyapaikan pesan, dan media pembelajaran adalah segala sesuatu yang dapat di gunakan untuk menyalurkan pesan serta dapat merangsang pikiran, perasaan, perhatian, dan kemauan belajar sehingga dapat mendorong terjadinya proses belajar yang di sengaja, bertujuan, dan terkendali.

Dari sinilah dapat diketahui bahwa peran media pembelajaran sangat penting bagi siswa dalam menunjang proses pembelajaran. Selain itu, berdasarkan hasil observasi di MTs. Mafatihul Huda pujon, dapat diketahui bahwa pendayagunaan fasilitas yang tersedia di sekolah belum begitu maksimal. Penyampaian materi pelajaran Matematika sangatlah jarang menggunakan media yang tersedia, namun lebih dominan menggunakan papan tulis. Pembelajaran seperti ini dinilai kurang variatif dan cenderung pasif, karena siswa tidak sepenuhnya menjadi pelaku namun lebih condong sebagai pendengar dalam proses kegiatan belajar mengajar. Dengan upaya untuk memberikan solusi tehadap permasalahan yang ada dengan menyajikan sebuah media pembelajaran interaktif berupa media Hand Quick yang memiliki berbagai kelabihan di antaranya dapat memudahkan anak dalam menerima materi baru karena metode ini diberikan secara menyenangkan maka sistem limbic di otak anak akan senantiasa terbuka, sehingga menciptakan kondisi pembelajaran yang kondusif yang nantinya akan bermuara pada keberhasilan siswa dalam belajar.

\section{METODE}

Jenis penelitian ini adalah penelitian pengembangan, yaitu suatu penelitian yang bertujuan untuk mengembangkan suatu produk dengan mengacu pada Metode penelitian model ADDIEyang direkomendasikan oleh Borg dan Gall (2003) subyek penelitian pada penelitian ini adalah siswa kelas VII MTs. Mafatihul Huda Pujon, yang terletak di Jl. Diponego ro No. 01 Bengkaras Madiredo Pujon, Kabupaten Malang.

Prosedur pengembangan media pembelajaran matematika Hand Quick ini dikembangkan dengan model ADDIE melalui beberapa tahap antara lain sebagai berikut :

1. Tahap Analisis ( Analysis )

Tahap analisis merupakan suatu proses yang akan mendefinisikan apa yang dipelajari oleh siswa.

2. Tahap Perancangan ( Design)

Tujuan tahap perancangan adalah untuk mempersiapkan segala hal yang dibutuhkan dalam pengembangan media agar media yang dikembangkan dapat mendukung pelajaran di sekolah.

3. Tahap Pengembangan (Development)

Tujuan tahap pengembangan adalah untuk mengembangkan media guna mencapai tujuan pembelajarn yang telah dirumuskan sebelumnya.

4. Tahap Implementasi (Implementation)

Tahap implementasi adalah langkah nyata untuk menguji coba produk.

5. Tahap Evaluasi (Evaluation)

Tahap evaluasi adalah proses untuk melihat apakah media yang sedang dikembangkan berhasil, sesuai dengan harapan awal atau tidak.

\section{HASIL DAN PEMBAHASAN}

Berdasarkan model pengembangan ADDIE, langkah - langkah pengembangan media Hand Quick pada materi perkalian bilangan bulat siswa kelas VII MTs. Mafatihul Huda Pujon dilakukan melalui tahap berikut :

1. Tahap Analisis (Analysis)

a. Analisis Kebutuhan 
Pada penelitian ini, analisis kebutuhan dilakukan dengan cara menggali dan mengumpulkan informasi- informasi penting terkait dengan masalah yang terjadi dalam pembelajaran matematika siswa kelas VII MTs. Mafatihul Huda Pujon.

b. Analisis Kurikulum

Analisis kurikulum dilakukan dengan menganalisis kompetensi inti dan kompetensi dasar serta indikator pencapaian kompetensi dengan mengacu pada Kurikulum 2013.

c. Analisis Karakteristik Siswa

Analisis karakteristik siswa bertujuan untuk mengetahui karakteristik siswa yang akan menggunakan media yang dikembangkankan. Analisis dilakukan selama peneliti melaksanakan kegiatan belajar mengajar. Dari hasil analisis didapatkan bahwa siswa kelas VII memiliki kemampuan yang beragam. Hal ini dapat dilihat dalam pembelajaranmisalnya terdapat siswa yang bertanya kepada guru jika menemui kesulitan.

\section{Tahap Perancangan (Design)}

a. Pembuatan desain media

Desain media menggambarkan secara keseluruhan hubungan antara bagian media. Desain media dibuat untuk memudahkan proses pembuatan media selanjutnya dan berfungsi sebagai peta pada panduan pembuatan media.

Contoh : Perkalian $7 \times 8$ (perhatikan gambar di bawah ini) sentuh jari-jarinya

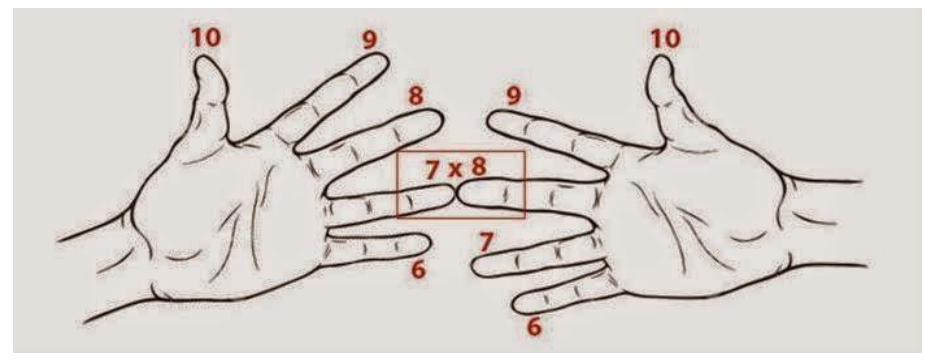

Gambar 1 : Perkalian Jari Tangan

Hitung jarinya, (jari yang bagian bawah) setiap jari yang menyentuh hitung sebagai puluhan (jumlah jarinya $5=5$ puluhan atau 50)

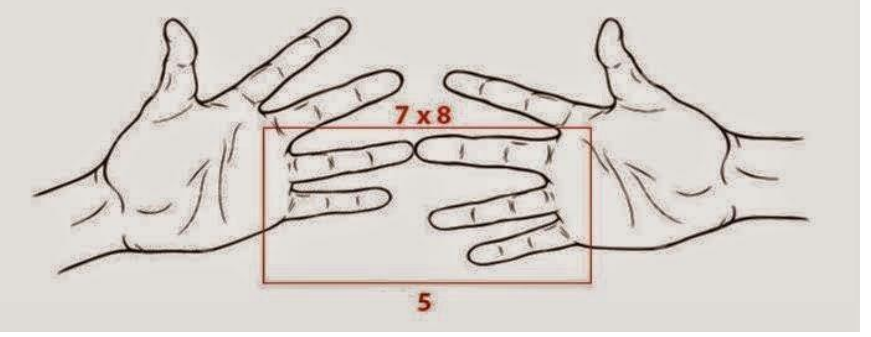

Gambar 2 : Perkalian Jari Tangan

selanjutnya, kalikan jari-jari sisanya untuk menemukan satuan (contoh diatas,3 jari dikali 2 jari $=6$ ) tambahkan satuan ke puluhan, dan sekarang hasilnya adalah 56

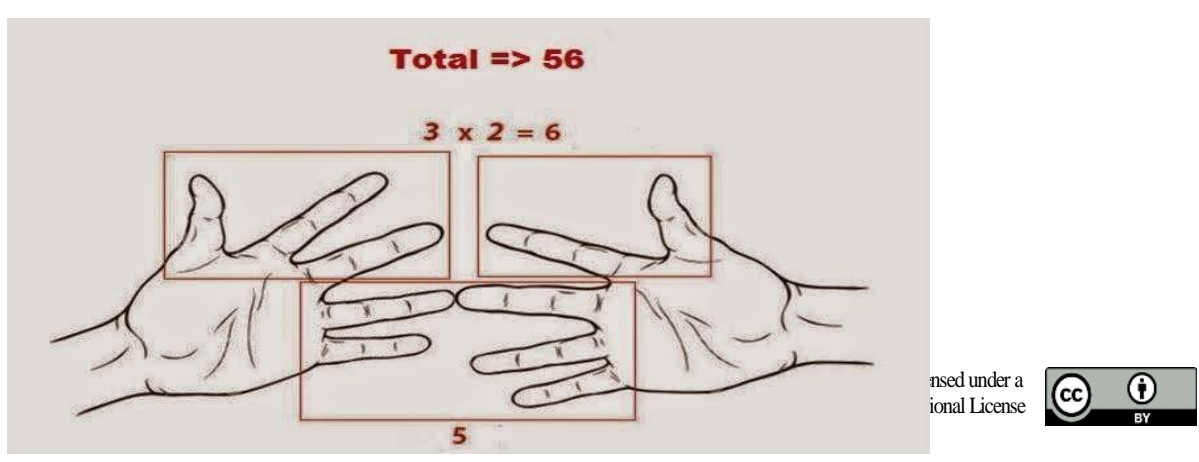


Gambar 3 : Perkalian Jari Tangan

Desain dari media pembelajaran matematika Hand Quick yang telah dikembangkan bisa dilihat dari gambar desain di bawah ini.

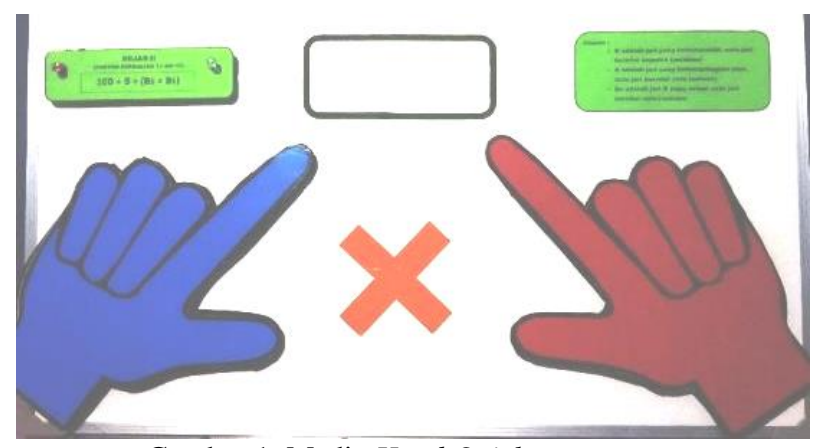

Gambar 1. Media Hand Quick

b. Penyusunan instrument penilaian kelayakan media

Pada tahap desain juga disusun instrumen penilaian kelayakan media yang dikembangkan berupa angket daftar isian (check list ) untuk ahli matematika dan siswa. Pada tahap ini diawali dengan penyusunan kisi - kisi angket, hasil penyusunan angket dari tahap ini diperoleh angket validasi yang akan diberikan kepada dosen matematika dan guru matematika untuk mengetahui kelayakan media serta angket untuk mengetahui respon siswa terhadap media pembelajaran tersebut.

3. Tahap Pengembangan (Development)

Pada tahap ini dilakukan pembuatan media meliputi penentuan isi materi, validasi dan produksi. Isi materi berdasarkan pada Kurikulum yang ditetapkan sebelumnya. Sehingga dihasilkan media yang menarik sesuai dengan Kurikulum yang diberlakukan di MTs. Mafatihul Huda Pujon.

4. Tahap Implementasi (Implementation)

Tahapan implementasi dilakukan ujicoba pada 10 siswa kelas VII MTs Mafatihul Huda Pujon. Analisis hasil uji kompetensi dan hasil angket respon siswa mendapatkan kriteria baik dari semua siswa dengan rata-rata nilai 85 .

Dari hasil presentasi ketuntasan belajar siswa diperoleh media Hand Quick termasuk kategori sangat baik atau dapat dikatakan efektif digunakan sebagai media pembelajaran.

5. Tahap Evalusi

Pada tahap ini sudah tidak dilakukan perbaikan terhadap media yang dikembangkan karena dilihat dari angket respon siswa menunjukkan hasil baik. Jadi dapat disimpulkan produk akhir yang dihasilkan peneliti dikategorikan baik / layak digunakan sebagai media ajar dalam pembelajaran matematika di sekolah.

\section{SIMPULAN DAN SARAN}

Berdasarkan hasil penelitian dan pembahasan terhadap media Hand Quick yang dikembangkan, maka dapat disimpulkan sebagai berikut : Pembelajaran Matematika Berbasis Hand Quick Pada Materi Operasi Bilangan Bulat Siswa Kelas VII MTs. Mafatihul Huda Pujon menggunakan model ADDIE ( Analysis, Design, Development, Implementation, dan Evaluation)

Kualitas media Hand Quick yang telah dikembangkan sebagai berikut : (1) Ditinjau dari kevalidan, yaitu penilaian validator dari beberapa aspek. Aspek Media memperoleh skor 3,5 dengan kategori sangat valid, aspek materi diperoleh skor 3,0 dengan kategori valid, sedangkan aspek bahasa memperoleh skor 3,5 dengan kategori sangat valid. Hal ini menunjukkan bahwa media pembelajaran matematika Finger-Smart yang dikembangkan peneliti dinyatakan sangat valid. (2) Ditinjau dari keefektifan, yaitu analisis angket respon diperoleh skor 3,8 dari skala. Hal ini menunjukkan hasil penelitian termasuk dalam kategori baik. Selain itu keefektifan juga dilihat dari rata-rata uji kompetensi siswa dimana diperoleh rata- rata 84 dengan kategori baik. Dari hasil tersebut dapat disimpulkan bahwa media Hand Quick yang dikembangkan dinyatakan efektif digunakan sebagai media ajar. 
Produk yang di kembangkan dapat di gunakan sebagi media belajar siswa secara mandiri di rumah. Dan juga guru di sarankan dapat memanfaatkan keunggulan media Hand Quick dengan cara mengembangkan materi pembelajaran lainnya sebagai bentuk media pembelajaran interaktif. Selain itu masih perlu adanya pengembangan media sebagai media interaktif yang lebih menarik lagi pada bidang pembelajaran khususnya pembelajaran matematika.

\section{DAFTAR RUJUKAN}

Arikunto, Suharsimi. (2010). Prosedur Penelitian Suatu Pendekatan Praktik. Jakarta:Rineka Cipta. Arsyad, Azhar. (2002). Media Pembelajaran. Jakarta: PT. Rajagrafindo Persada.

Arsyad, Azhar. (2006). Media Pembelajaran. Jakarta: PT. Rajagrafindo Persada.

Gall, Meredith D., Gall, J.P. \& Borg, W.R. (2003). Educational Reseach An Introduction 7thEdition. Boston: Pearson Education.

Darmini, Anak Agung Sagung Rai, (2009). Pemanfaatan Teknologi Informasi dan Pengaruhnya Pada Kinerja Individual Pada Bank Perkreditan Rakyat di Kabupaten Tabanan. Universitas Udayana Denpasar.

Hamalik, Oemar. (2011). Kurikulum dan Pembelajaran. Jakarta: Bumi Aksara.

Hendra. (2008). Aneka Berhitung Cepat. Bogor: R3W Media. Miarso, Yusufhadi. 2004. Menyemai Benih Teknologi Pendidikan. Jakarta: Prenada Media

Nasution, Tetty Khairani dan Edy Surya. (2015). Penerapan Teknik Jarimatika dalam Upaya Meningkatkan Kemampuan Operasi Hitung Perkalian Bilangan. Edumatica, 5 (1), 48-58.

Palupi, Anisa Tri. (2012). Penggunaan Media Jarimatika Untuk Meningkatkan hasil Belajar Matematika Materi Perkalian pada Siswa Kelas IV SD Negeri Combongan 03 Sukoharjo. Skripsi. Surakarta: UMS. Tidak Dipublikasikan.

Pribadi, Benny A. (2009). Model Desain Sistem Pembelajaran. Jakarta: Dian Rakyat.

Belajar Matematika Kelas IV SD Negeri 06 Metro Barat Tahun pelajaran 2015/ 2016. Skripsi. Bandar Lampung: Universitas Lampung. Tidak Dipublikasikan.

Santyasa, I Wayan. (2017). Model-Model Pembelajaran Interaktif. Makalah disajikan dalam Pelatihan tentang Penelitian Tindakan Kelas bagi Guru- Guru SMP an SMA, Nusa Penida, 29 Juni - 1 Juli 2007

Rahmatullah, Bima Suci. (2016). Pengaruh Penggunaan Metode Jarimatika terhadap Hasil 